\title{
The Exploration of Cultivating Students in College English Teaching
}

\author{
Fangrong Liu \\ School of Foreign Languages \\ Wuhan Textile University \\ Wuhan, P.R.China \\ E-mail: 178146790@qq.com
}

\begin{abstract}
Since ancient times, teaching knowledge and cultivating students have been closely connected. Teaching knowledge and cultivating students are two aspects of education and they have been consistent with each other. Cultivating students is indispensable in college English teaching. Equal relationship between teachers and students, strict teaching instructions, creative teaching activities and surprising prizes can promote college English teaching results, bridge the gap between teachers and students and can be effective in cultivating students.
\end{abstract}

Keywords-college English teaching; teaching knowledge, cultivating students

\section{INTRODUCTION}

In the exposure draft on the Teaching Guidelines for College English of 2015 version, it is clearly specified that English, as the most widely used language in the world, is the important tool for international exchanges, scientific and cultural communication. Through learning and using English, people can directly understand the latest scientific advancement, managing experience and new thoughts and concepts in the world, learn and understand the brilliant world culture and civilization. Meanwhile, learning and using English can be helpful in increasing the language power in China, spreading Chinese culture, promoting the communication with the people in different parts of the world and enhancing the national soft power. College English course in the universities, on the one hand, meets the national strategy demand and serves the reform and openingup and economic development; on the other hand, it fulfils the need of students in major study, international exchanges, further study and job hunting. For college students, it has the realistic and far-reaching effects on the future development. Learning English can help students form the world perspectives, cultivate the international consciousness, enhance humanistic quality, and provide an essential tool for students' knowledge innovation, potential application and overall development, to prepare for the coming challenges and opportunities in the global age. Therefore, college English teaching is deeply involved in teaching knowledge and cultivating students.

The article is sponsored by the 2013 teaching research program of Wuhan Textile University: The Influence of Oral English Training on Students' Critical Thinking Capability Development on the Basis of CBI(2013wx005) .

\section{THE HistORIC ORIGIN}

Since the ancient time, in China and foreign countries, teaching knowledge and cultivating students have been closely related to each other. In the history of western education, Grecian Socrates thought that knowledge is virtue and that education is to make the educated become "the most brilliant and useful person"[1]. During the renaissance, the famous educator Comenius thought that the aim of education is to cultivate the persons who are knowledgeable, virtuous and pious [2].

In China, Confucius, the great educator, thought that people should enrich themselves with cultural knowledge and restrict themselves to etiquette (the Analects, Zihan). That is, through the cultivation of virtues, the good social atmosphere can be formed and people can restrict their own behaviors and restore the politeness. The educational thoughts of Confucius have been greatly influencing Chinese educational development for thousands of years. The Book of Rites said, "teachers are the ones who teach students knowledge as well as virtues." [3] That is, the knowledge taught by teachers is just what the virtues come from. Han $\mathrm{Yu}$ thought, in his Shishuo, that a teacher is the one who could propagate the doctrine, impart professional knowledge, and resolve doubts. During the late Ming dynasty and early Qing dynasty, the first educator Sun Xiafeng said in Family instructions on teaching children, "the ancient people did a lot of reading to be graded in the imperial examination, in which way they could understand the principles and be good persons."'[4] The great educator Tao Xingzhi once presented, "whatever you teach students is to teacher them to seek for truth, while whatever the students learn is to help them learn to be persons with good virtues." Those points revealed the inexorable law of teaching knowledge and cultivating students from different perspectives and highlighted the importance of teaching knowledge and cultivating students.

\section{THE CONSISTENCY BETWEEN TEACHING KNOWLEDGE AND CULTIVATING STUDENTS}

Teaching knowledge and cultivating students can be understood from two aspects: teaching knowledge and cultivating students. Teaching knowledge itself is the process of information-based education, of knowledge delivery and 
of knowledge-based learning, while cultivating students is the process of perceptual and characterized teaching which influences students' emotional qualities when they join in the social activities, such as ideology, virtues, character and thoughts. Teaching knowledge and cultivating students are two aspects of education and they are consistent with each other. Teaching knowledge itself involves the cultivation of students. A teacher must have some certain political concepts, values and virtues, which influence students' political ideas.

Teachers in the universities should make use of right points to organize teaching activities and influence students with serious attitudes, hence leading students to grow up in the right direction and form correct world views and methodology. Meanwhile, teachers must fully understand the importance of teaching knowledge and cultivating students and realize the integration of them, to be good at teaching knowledge and cultivating students.

\section{How to Cultivate StUdents IN ENGLish TEACHING}

According to the modern educational concepts, a teacher usually plays a dominant role in teaching activities and students play a major role. English teaching is a secondlanguage teaching. In terms of second language teaching rules, a teacher still plays a dominant role in the process of language learning, esp. in the form of classroom teaching. During college days, college students have to study English for two years and English teachers play an very important role in the growing process of college students. How do college English teachers cultivate students in these two years?

\section{A. Equal teacher-student relationship is the cornerstone of cultivating students.}

Equality is one of the basic characteristics of teacherstudent relationship. How to understand and build a harmonious and equal teacher-student relationship greatly influences the heart-to-heart communication between teachers and students, the happiness involved in the communication process and the directivity of student development.

In politics, equality is regarded as not only a philosophical concept (emphasizing the natural equality, that is, human beings are equal animals), but also a distribution principle (referring to people's equality in the distribution of income, social chances and political rights). Therefore, the equal teacher-student relationship is firstly reflected in the equal social status, secondly in the equal opportunity to receive knowledge, and thirdly the natural equality. The challenge taken by social development against education is the relationship between teachers and students. Teachers should treat students as friends and the relationship between them must be built on the basis of equality.

In universities, students are 18 or 19 years old young people with independent ideas, full of passion and ideals. College English teachers must get rid of their traditional ideas and try to make friends with students, exchanging ideas and cultivating them. Actually, in treating the students, I always stick to one rule: making friends with students and treating them equally. During the two years with students, I remembered the name of each student, could communicate with students the daily life topics besides English knowledge, such as making friends, movies and TV plays, songs, shopping, clothes, makeup and games, etc., which can shorten the distance between teachers and students and teach some life philosophy to students. Thus, students know how to respect other people, care about other people, be good to other people and communicate with others.

\section{B. Strict teaching instructions guarantee the cultivation of students.}

The so-called teaching instructions are rules obeyed in the talent-fostering activities involved in the teaching of teachers and the learning of students. According to those rules, teachers must lead students to the mastery of cultural and scientific basic knowledge, promote the whole-sale improvement of student's qualities and make them the useful persons for the society.

English teaching instructions in universities consist of three levels: general level, higher level and much higher level. Those are the standards non-English undergraduates must reach after they have been through English study and practice in the college days. General level is the basic level non-English-major graduates should reach. Higher or much higher levels are recommended for those universities which can set up their own standards according to their orientation and objectives of training talents. All universities have to set up their own goals according to their own realities and try to help those students who are better than others to reach the higher or much higher levels.

English teachers should also make the proper teaching instructions suitable for their own students to ensure the smooth implementation of teaching activities. I have tried the following ways among my own students:

Make the classroom rules. Students are not allowed to play with their cell phones, to sleep in classes, to come into or go out of the classroom freely in class. They must listen to the teacher very carefully, answer questions actively and finish the assignments quickly, in which way college students gradually form the regulation awareness.

Make the learning instructions. Students are very clear about how many texts they have to recite, how many words they have to write in a good composition, how long they have to do the listening and how many words they have to memorize. Thus, college students have to be very hard and learn attentively.

Teaching instructions can be effective in improving students' learning efficiency and facilitating the teaching of teachers and the learning of students.

\section{Creative teaching activities is the lubrication of cultivating students.}

Teaching activities are English activities involved in opera creation, reading English poems, singing English songs, English speech, debate. These activities can facilitate 
the English teaching and keep students feel fresh and enthusiastic in English learning.

In teaching college English, I usually make use of those activities to foster the creative thoughts of students and encourage them to communicative effectively with other people. College English books are abundant in English knowledge, but containing a lot of English words students don't know. They sometimes feel frustrated when learning English and need to receive something new.

Therefore, an English opera show was once designed for them where six or seven must form a group, members of which as a team have to find acting materials, write scripts, assign characters, make acting devices and do a lot of rehearsals. In the following week, all students were very busy in rehearsing their operas. You must have heard the story of Jin Ke killing Emperor Qin, but you have never heard the story of the fight between Li Mochou and Jin Ke on the top of Forbidden

City, the changing plot of Jack and Rose. Students made full use of their unlimited creativity to let them experience the power of a team and better relationship between them. For me, the opera show fully demonstrate the unexpected effect of creative teaching activities in English classes.

\section{Surprising prizes are facilitators of cultivating students.}

College students are young people of 18 or 19 years old, but they are still kids in teachers' eyes. Some surprising prizes can be the powerful facilitators of cultivating students sometimes.

On the eve of Children's Day, I designed an open English class for students: buying ice creams for each student and allowing students to taste the ice cream when listening to the teacher. Those ice creams are the Children's Day presents for each student as well as rewards for their hard work in English learning. All students were eating their ice creams and listening to the teacher attentively at the same time, which could seldom happen in the ivory tower with strict teaching rules. However, through this surprising activity, students are more attentive in English classes and they form more harmonious relationship with the teacher. Even they are more thankful than before. Such effects cannot be reached through the oral lecturing.

\section{CONCLUSION}

Equal relationship between teachers and students, strict teaching instructions, creative teaching activities and surprising prizes can promote college English teaching results, bridge the gap between teachers and students and can be effective in cultivating students.

\section{REFERENCES}

[1] Xenophon. Recall Socrates[M]. translated by Wu Kangquan. Beijing: Commercial Press, 2013.

[2] Liu Minghan, Chen Mingli. The History of European Renaissance[M]. Beijing: People's Press, 2008.
[3] Feng Youlan. The History of Chinese Philosophy[M]. Chongqing Chongqing Press, 2009.

[4] Chen Qingzhi. The History of Chinese Education [M]. Changsha: Yuelu Publishing House, 2010. 